
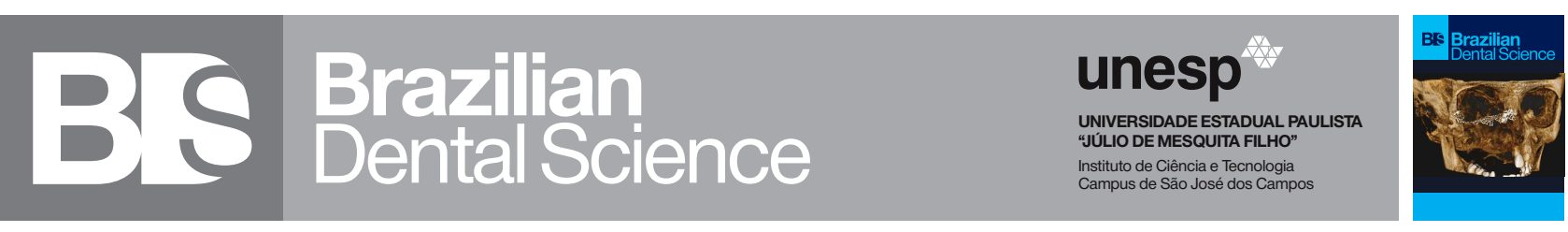

\title{
Clinical Evaluation of Postoperative Sensitivity in Class I Resin Composite Restorations
}

Avaliação clínica da sensibilidade pós-operatória em restaurações classe I em compósitos restauradores

Renan Menezes CARDOSO ${ }^{1}$, Bruno Mendonça Lucena DE VERAS ${ }^{1}$, Marlus da Silva PEDROSA ${ }^{2}$, Claudio Heliomar Vicente DA SILVA ${ }^{3}$

1 - Course of Dentistry - Federal University of Pernambuco - Recife - Pernambuco - Brazil.

2 - Department of Biomaterials and Oral Biology - School of Dentistry - University of São Paulo - São Paulo - Brazil.

3 - Department of Prosthodontics and Buco-Facial Surgery - Federal University of Pernambuco - Recife - Brazil.

\section{ABSTRACT}

Objective: To evaluate the postoperative sensitivity in posterior restorations with different resin composites and adhesive systems as well as the influence of the depth and extent of the dental cavity. Material and Methods: A doubleblind clinical trial was carried out with 80 class I restorations of 16 patients. The participants were divided into 4 groups according to the adhesive system + composite: $\mathrm{F}+\mathrm{P}$ (Filtek $\left.\mathrm{P}^{\mathrm{TM}}+\mathrm{P}^{\mathrm{TM}}{ }^{\mathrm{TM}}\right) ; \mathrm{R}+\mathrm{S}\left(\mathrm{Rok}^{\mathrm{TM}}+\mathrm{Stae}^{\mathrm{TM}}\right) ; \mathrm{P}+$ $\mathrm{A}\left(\mathrm{P} 60^{\mathrm{TM}}+\right.$ Adper SE PLUS $\left.{ }^{\mathrm{TM}}\right) ; \mathrm{E}+\mathrm{X}\left(\right.$ Evolux $^{\mathrm{TM}}$ $+\mathrm{XPBond}^{\mathrm{TM}}$ Adhesive). After 7, 15 and 30 days, the presence of postoperative sensitivity was evaluated and classified according to type and intensity. The data were submitted to Pearson's chi-square test, Fisher's exact teste, Student's t-test and ANOVA. A significance level of 5\% was used for all tests. Results: The presence of postoperative sensitivity was approximately $6 \%$ of the total sample. The sensitivity decreased with the evaluation time, with the smallest reduction occurring from the 7-day evaluation compared to the other evaluations. Conclusion: There was found no evidence of influence of the resin composite and adhesive type, depth and extension of the cavities for the presence of postoperative sensitivity.

\section{KEYWORDS}

Dentistry; Dentin sensitivity; Adhesives; Composite resins.

\section{RESUMO}

Objetivo: Avaliaraprevalênciadasensibilidadepósoperatória em dentes posteriores restaurados com diferentes resinas compostas e sistemas adesivos em relação a profundidade e extensão da cavidade dental. Material e Métodos: Estudo clinico duplocego foi realizado com 80 restaurações classe I em 16 pacientes. Os pacientes foram divididos em 04 grupos de acordo com compósito restaurador e sistema adesivo: $\mathrm{F}+\mathrm{P}$ (Filtek $\left.\mathrm{P}^{\mathrm{TM}}+\mathrm{P}^{\mathrm{TM}} 0^{\mathrm{TM}}\right) ; \mathrm{R}$ $+\mathrm{S}\left(\right.$ Rok $\left.^{\mathrm{TM}}+\mathrm{Stae}^{\mathrm{TM}}\right) ; \mathrm{P}+\mathrm{A}\left(\mathrm{P}^{\mathrm{TM}}{ }^{\mathrm{TM}}+\right.$ Adper SE PLUS $\left.^{\mathrm{TM}}\right) ; \mathrm{E}+\mathrm{X}\left(\right.$ Evolux $^{\mathrm{TM}}+\mathrm{XPBond}^{\mathrm{TM}}$ Adhesive). Após 7, 15 e 30 dias, a presença de sensibilidade pós-operatória foi avaliada e classificada quanto ao tipo e intensidade. Os dados foram analisados estatisticamente mediante os testes estatísticos qui-quadrado de Pearson, exato de Fisher, t de Student e ANOVA. Um nível de significância de 5\% foi utilizado para todas as analises. Resultados: A presença de sensibilidade pós-operatória foi de aproximadamente $6 \%$ na amostra. A sensibilidade reduziu com o tempo de avaliação, sendo que a menor redução ocorreu da avaliação de 7 dias para as outras avaliações e a menor de 15 para 30 dias. Conclusão: Não se evidenciou influência do tipo de compósito e adesivo, profundidade e extensão das cavidades na presença de sensibilidade pósoperatória.

\section{PALAVRAS-CHAVE}

Odontologia; Sensibilidade da dentina; Adesivos; Resinas compostas. 


\section{INTRODUCTION}

$T^{1}$ he success in direct restorations is attributed to their functionality and longevity. The esthetic standards in modern society and the improvement of restorative materials have made resin composites an alternative to amalgam restorations, since by using resin composites it is possible to mimic the optical behavior of the dental structure $[1,2]$.

The clinical success with resin composites allows their safe use in anterior and posterior teeth $[1,3]$. A decisive fact in this context is the adhesive technology [4,5]. Initially, the adhesive systems used acted by the conventional adhesive technique and had several preliminary steps to insert the resin composite, making the protocol susceptible to errors [6]. With the incorporation of acidic resin monomers to the composition of the bonding agents, the selfetching technology came out, which eliminated steps of the conventional adhesive technique, such as washing and drying the cavity [7].

Despite technical and scientific advances, postoperative sensitivity is still a concern in restorative procedures [8-15]. It can be defined as a toothache, after restorative procedure, associated with the contact with thermal, chemical and mechanical stimuli, which produce fluid movement inside the dentinal tubules $[10,16]$.

The objective of present study was to evaluate the presence of postoperative sensitivity in posterior teeth restored with different types of resin composites and adhesive systems as well as the influence of the depth and extension of the dental cavity.

\section{MATERIALS AND METHODS}

This double-blinded clinical trial was approved by the Research Ethics Committee of the Centro Integrado de Saúde Amaury de Medeiros (CISAM), Recife, PE, Brazil (\# 0003.1.250.000_10). Eighty Class I restorations were performed in molars and premolars of sixteen male $(n=5)$ and female patients $(n=11)$, aged between 23 and 46 years, of the CISAM. Sample size was calculated according to previous studies $[13,17,18]$. The restorations were divided into four groups according to adhesive system and the resin composite used (Figure 1). Table I shows the group distribution and manufacturer's information regarding the resin composites and adhesive systems used in the study.

Table I - Group distribution and manufacturer's information regarding the resin composites and adhesive systems used in the study.

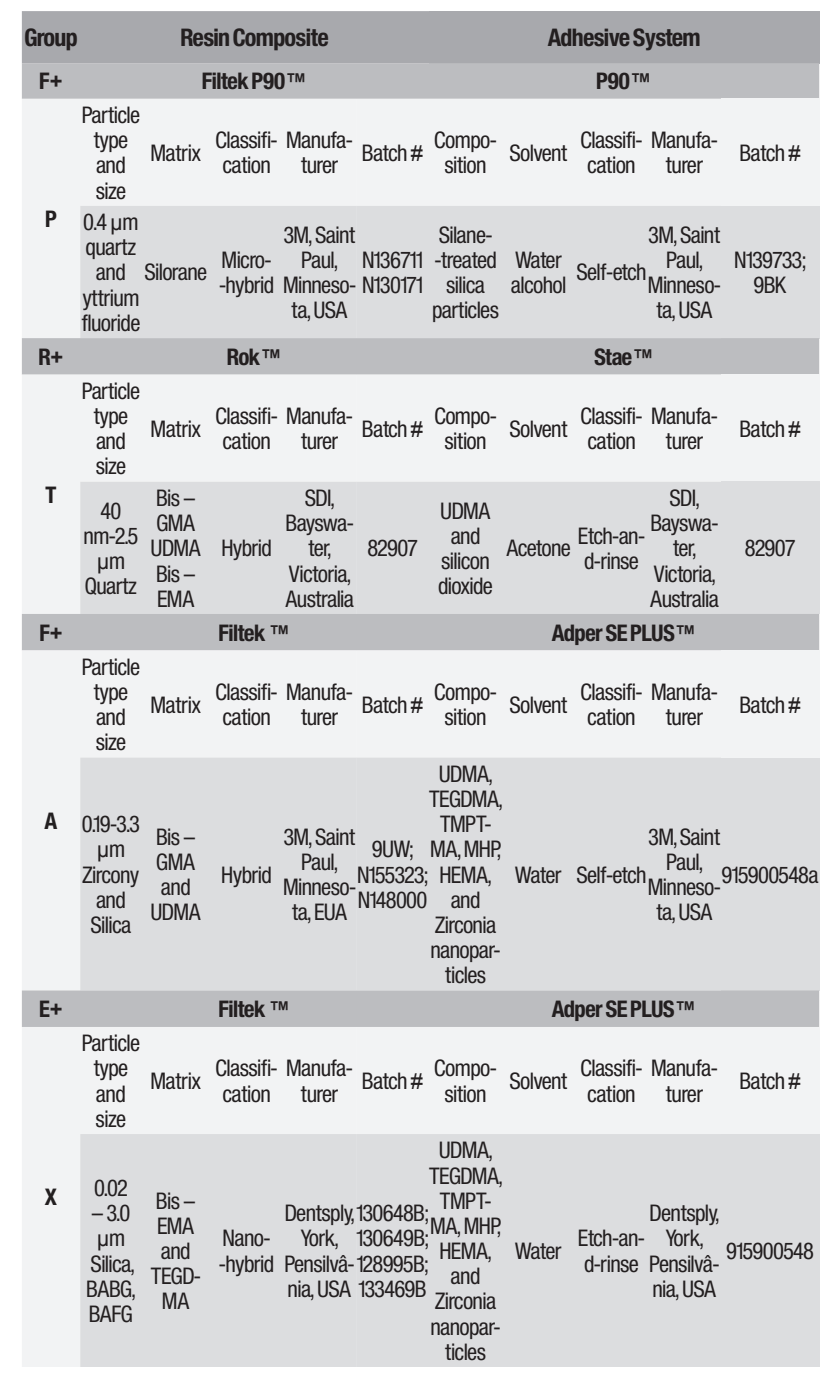




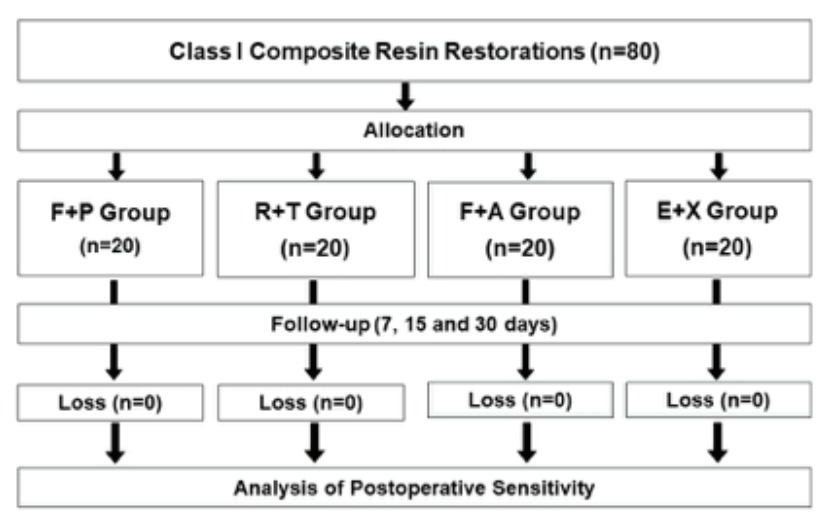

Figure 1- Study flowchart.

Inclusion criteria were patients over 21 years of age and in need of restorative treatments on the occlusal surfaces of at least four posterior teeth and the antagonistic teeth should be healthy or satisfactorily restored. Patients with dental elements antagonistic to non-healthy restorations, missing or not satisfactorily restored, restored with ceramic material and with removable denture were excluded.

Detailed anamnesis and clinical examination were performed. Before starting the restorative procedures, the patients were instructed regarding diet and oral hygiene. All the patients who agreed to participate in the study signed the consent form. All clinical procedures were performed by a single calibrated operator, who was blind to the clinical procedure. A previous pilot study was performed to ensure operator calibration. The patient was also unaware of the materials used in each restoration.

The restorative procedures were carried out after local anesthesia and rubber dam isolation. Color match was performed under natural light by placing and curing an increment of resin composite on the tooth crown. Cavity preparations were limited to the removal of affected dentin [19-21] and were performed with \#1014, \#1015 and \#1046 diamond burs (SSWhite, Juiz de Fora, Minas Gerais, Brazil) at high speed under copious water cooling and \#1/2, \#1, \#2 and \#3 (KG Sorensen, Cotia, São
Paulo, Brazil) in low speed. The diamond burs were discarded every five preparations.

After cavity preparation and rubber dam isolation of the operative field, prophylaxis with pumice (SSWhite, Juiz de Fora, Minas Gerais, Brazil) and water with the aid of a Robinson brush (KGSorensen, Cotia, São Paulo, Brazil) was performed. The cavities were washed and dried. Pulp capping procedures followed the guidelines of the Brazilian Group of Operative Dentistry Professors [22]. The restorative procedures followed the recommendations of the manufacturers regarding the use of the adhesive system and the resin composite (Table II). A Radii-call LED curing unit (SDI, Bays water, Victoria, Australia) was used for all photo polymerization procedures.

Table II - Restorative procedures according to groups.

\begin{tabular}{|c|c|}
\hline$F+P$ & $\begin{array}{l}\text { 1. Enamel etching for } 15 \text { seconds } \\
\text { 2. Washing and drying the cavity } \\
\text { 3. Active application of the primer for } 15 \text { seconds } \\
\text { 4. Light-curing for } 10 \text { seconds } \\
\text { 5. Active application of the adhesive system followed by air jet } \\
\text { 6. Light-curing for } 10 \text { seconds } \\
\text { 7. Incremental application ( } 2 \text { mm each) of the composite resin } \\
\text { 8. Light-curing for } 40 \text { seconds (each increment) }\end{array}$ \\
\hline $\mathrm{R}+\mathrm{S}$ & $\begin{array}{l}\text { 1. Cavity etching for } 20 \text { seconds } \\
\text { 2. Washing and drying the cavity } \\
\text { 3. Application of the adhesive for } 15 \text { seconds; } \\
\text { 4. Light-curing for } 10 \text { seconds; } \\
\text { 5. Incremental application ( } 2 \mathrm{~mm} \text { each) of the composite resin } \\
\text { 6. Light-curing for } 20 \text { seconds (each increment); }\end{array}$ \\
\hline$P+A$ & $\begin{array}{l}\text { 1. Enamel etching for } 15 \text { seconds } \\
\text { 2. Washing and drying the cavity } \\
\text { 3. Application of liquid A } \\
\text { 4. Application of liquid B and wait for the red color disappear } \\
\text { 5. Light-curing for } 10 \text { seconds } \\
\text { 6. Adhesive air-drying } \\
\text { 7. Application of liquid B } \\
\text { 8. Air-drying } \\
\text { 9. Light-curing for } 10 \text { seconds } \\
\text { 10. Incremental application ( } 2 \mathrm{~mm} \text { each) of the composite resin } \\
\text { 11. Light-curing for } 20 \text { seconds (each increment) }\end{array}$ \\
\hline$E+X$ & $\begin{array}{l}\text { 1. Cavity etching for } 20 \text { seconds } \\
\text { 2. Washing and drying the cavity } \\
\text { 3. Application of the adhesive } \\
\text { 4. Air-drying and light-curing for } 10 \text { seconds } \\
\text { 5. Incremental application ( } 2 \mathrm{~mm} \text { each) of the composite resin } \\
\text { 6. Light-curing for } 20 \text { seconds (each increment) }\end{array}$ \\
\hline
\end{tabular}


After the restorations were completed, occlusal analysis was performed and interferences were removed with \#2200 and \#2112 diamond burs (KG Sorensen, Cotia, and São Paulo, Brazil). After 24 hours, finishing and polishing of the restorations were carried out with diamond burs, Enhance finishing points (Dentsply, York, Pensilvânia, USA) and polishing paste (Diamond - FGM, Joinville, Santa Catarina, Brazil).

After 7, 15 and 30 days, the patients were asked about the postoperative sensitivity associated with the restored teeth using a 11-point verbal numeric scale [23], which, when existing, was classified according to the intensity and the type (spontaneous or provoked) [24,25].

Normal data distribution was verified, and statistical analysis was carried out using the SPSS software ver. 22.0 (IBM, Armonk, NY, USA). Data are presented as mean \pm standard deviation (SD). Pearson's chi-square and Fisher's exact tests were used to verify differences between groups regarding age and sex, respectively. Student's t-test was used to verify differences in postoperative sensitivity between shallow and deep cavities. The choice of the F test (ANOVA) was due to the absence of alternative techniques (non-parametric test type) for the comparison of repeated measures and its robustness in relation to the absence of normality or heterogeneity of variances. A significance level of $5 \%$ was used for all statistical analysis.

\section{RESULTS}

The prevalence of postoperative sensitivity was approximately $6 \%$ of the total sample. Groups F + P and F + A had a sensitivity of $15 \%$ and $10 \%$ respectively. Patients in groups $\mathrm{R}+\mathrm{T}$ and $\mathrm{E}+\mathrm{X}$ did not report postoperative sensitivity.

Table III shows the age and sex according to the group. In the total group, the highest frequency corresponded to patients aged 26 to 29 years $(40.0 \%)$, followed by those aged 30 or over $(35.0 \%)$ and 20 to 25 years $(25.0 \%)$. The majority $(80.0 \%)$ of the patients were female.
Postoperative sensitivity according to evaluation time is presented in table IV. Sensitivity decreased with evaluation time. In 7-day evaluation, there was no reported sensitivity in the Evolux ${ }^{\mathrm{TM}}$ group (0.00), 0.25 in the $\mathrm{ROK}^{\mathrm{TM}}$ and varied from 0.75 to 0.90 for $\mathrm{P}^{\mathrm{TM}}$ and $\mathrm{P} 60^{\mathrm{TM}}$. In 15 days and 30 days, $\mathrm{P}^{\mathrm{TM}}{ }^{\mathrm{TM}}$ and $\mathrm{ROK}^{\mathrm{TM}}$ presented no sensitivity and the highest mean (0.45) was recorded for $\mathrm{P} 60^{\mathrm{TM}}$. The average sensitivity increased with evaluation time for Evolux ${ }^{\mathrm{TM}}$ whereas in other groups, there was a reduction from 7 to 15 days ( $\mathrm{p}>0.05)$.

\section{Considering cavity deep (Table V}

), postoperative sensitivity were slightly higher in medium/deep cavities in 7 and 15 days evaluation. Postoperative sensitivity decreased with the evaluation time among those with medium/deep cavity while there was a reduction in the evaluation from 7 to 15 days and a small increase from 15 to 30 days ( $>>0.05$ ) in teeth with shallow cavities.

Table VI shows the presence of no postoperative sensitivity in cavities with less than $1 / 3$ in any of the evaluations. In the evaluations performed in 7 and 15 days, no postoperative sensitivity was reported in cavities with $1 / 3$ of the tooth extension. In any of the evaluations, the averages of postoperative sensitivity were higher in cavities with more than $1 / 3$ of tooth extension ( $p>0.05)$.

Table III - Age and sex according to group

\begin{tabular}{|c|c|c|c|c|c|c|c|c|c|c|c|}
\hline \multicolumn{12}{|c|}{ Group } \\
\hline & \multicolumn{2}{|c|}{$F+P$} & \multicolumn{2}{|c|}{$R+T$} & \multicolumn{2}{|c|}{$\mathbf{P}+\mathbf{S}$} & \multicolumn{2}{|c|}{$E+P$} & \multicolumn{2}{|c|}{ Total } & \multirow{2}{*}{ p-value } \\
\hline & n & $\%$ & n & $\%$ & $\mathbf{N}$ & $\%$ & $\mathbf{N}$ & $\%$ & $\mathbf{N}$ & $\%$ & \\
\hline $\begin{array}{l}\text { Total } \\
\text { - Age }\end{array}$ & 20 & 100 & 20 & 100 & 20 & 100 & 20 & 100 & 80 & 100 & \\
\hline $20-25$ & 5 & 25 & 5 & 25 & 5 & 25 & 5 & 25 & 20 & 25 & $1.00^{(1)}$ \\
\hline $26-29$ & 8 & 40 & 8 & 40 & 8 & 40 & 8 & 40 & 32 & 40 & \\
\hline$\geq 30$ & 7 & 35 & 7 & 35 & 7 & 35 & 7 & 35 & 28 & 35 & \\
\hline \multicolumn{12}{|l|}{ - Sex } \\
\hline Male & 4 & 20 & 4 & 20 & 4 & 20 & 4 & 20 & 16 & 20 & $1.00^{(2)}$ \\
\hline Female & 16 & 80 & 16 & 80 & 16 & 80 & 16 & 80 & 64 & 80 & \\
\hline
\end{tabular}

(1): Pearson's chi-squared test; (2): Fisher's exact test 
Table IV - Age and sex according to group.

\begin{tabular}{|c|c|c|c|c|c|}
\hline & $F+P$ & $R+T$ & $P+S$ & $E+$ & \multirow[b]{2}{*}{ p-value* } \\
\hline & $\begin{array}{l}\text { Mean } \pm \\
\text { SD }\end{array}$ & $\begin{array}{l}\text { Mean } \pm \\
\text { SD }\end{array}$ & $\begin{array}{c}\text { Mean } \pm \\
\text { SD }\end{array}$ & $\begin{array}{l}\text { Mean } \pm \\
\text { SD }\end{array}$ & \\
\hline 7 days & $\begin{array}{c}0.75 \pm \\
1.83\end{array}$ & $0.25 \pm 1.12$ & $\begin{array}{c}0.90 \pm \\
2.77\end{array}$ & $\begin{array}{c}0.00 \pm \\
0.00\end{array}$ & 0.332 \\
\hline 15 days & $\begin{array}{c}0.00 \pm \\
0.00\end{array}$ & $\begin{array}{c}0.00 \pm \\
0.00\end{array}$ & $\begin{array}{c}0.45 \pm \\
1.39\end{array}$ & $\begin{array}{c}0.15 \pm \\
0.67\end{array}$ & 0.220 \\
\hline 30 days & $\begin{array}{c}0.00 \pm \\
0.00\end{array}$ & $\begin{array}{c}0.00 \pm \\
0.00\end{array}$ & $0.10 \pm 0.31$ & $\begin{array}{c}0.40 \pm \\
1.79\end{array}$ & 0.460 \\
\hline p-value ${ }^{\star \star}$ & 0.083 & 0.330 & 0.163 & 0.330 & \\
\hline \multicolumn{6}{|l|}{ Differences } \\
\hline 7 - 15 days & $\begin{array}{c}0.75 \pm \\
1.83\end{array}$ & $0.25 \pm 1.12$ & $\begin{array}{c}0.45 \pm \\
1.39\end{array}$ & $\begin{array}{c}-0.15 \pm \\
0.67\end{array}$ & 0.190 \\
\hline $7-30$ days & $\begin{array}{c}0.75 \pm \\
1.83\end{array}$ & $0.25 \pm 1.12$ & $\begin{array}{c}0.80 \pm \\
2.46\end{array}$ & $\begin{array}{c}-0.40 \pm \\
1.79\end{array}$ & 0.155 \\
\hline $15-30$ days & $\begin{array}{c}0.00 \pm \\
0.00\end{array}$ & $\begin{array}{c}0.00 \pm \\
0.00\end{array}$ & $\begin{array}{c}0.35 \pm \\
1.09\end{array}$ & $\begin{array}{c}-0.25 \pm \\
1.12\end{array}$ & 0.122 \\
\hline
\end{tabular}

*ANOVA F-test; **F-Statistic from repeated measures ANOVA.

Table V - Postoperative sensitivity according to cavity deep and evaluation time.

\begin{tabular}{|cccc|}
\hline \multicolumn{4}{c}{ Cavity Deep } \\
Evaluation & $\begin{array}{c}\text { Shallow } \\
\text { Mean } \pm \text { SD }\end{array}$ & $\begin{array}{c}\text { Medium/Deep } \\
\text { Mean } \pm \text { SD }\end{array}$ & p-value* \\
\hline 7 days & $0.45 \pm 1.67$ & $0.52 \pm 1.95$ & $\mathbf{0 . 8 7 6}$ \\
\hline 15 days & $0.13 \pm 0.68$ & $0.19 \pm 0.96$ & $\mathbf{0 . 7 7 6}$ \\
\hline 30 days & $0.17 \pm 1.10$ & $0.04 \pm 0.19$ & $\mathbf{0 . 5 3 8}$ \\
\hline p-value** & 0.227 & 0.180 & \\
\hline Differences & $0.32 \pm 1.41$ & $0.33 \pm 1.21$ & $\mathbf{0 . 9 6 9}$ \\
\hline 7 - 15 days & $0.28 \pm 1.96$ & $0.48 \pm 1.78$ & $\mathbf{0 . 6 6 0}$ \\
\hline $7-30$ days & $-0.04 \pm 0.81$ & $0.15 \pm 0.77$ & $\mathbf{0 . 3 2 6}$ \\
\hline
\end{tabular}

${ }^{*}$ Student's t-test, ${ }^{* *} F$-Statistic from repeated measures ANOVA.

Table VI - Postoperative sensitivity according to cavity extension and evaluation time.

\begin{tabular}{|ccccc|}
\hline \multicolumn{5}{c}{ Cavity Extension } \\
Evaluation & $<1 / 3$ & $=1 / 3$ & $<1 / 3$ & p-value* \\
& Mean \pm SD & Mean \pm SD & Mean \pm SD & \\
\hline 7 days & $0.00 \pm 0.00$ & $0.42 \pm 1.44$ & $0.67 \pm 2.12$ & 0.368 \\
\hline 15 days & $0.00 \pm 0.00$ & $0.00 \pm 0.00$ & $0.24 \pm 0.99$ & 0.398 \\
\hline 30 days & $0.00 \pm 0.00$ & $0.00 \pm 0.00$ & $0.20 \pm 1.15$ & 0.623 \\
\hline p-value ${ }^{\star *}$ & & 0.339 & 0.135 & \\
\hline Differences & & & & \\
\hline 7 - 15 days & $0.00 \pm 0.00$ & $0.42 \pm 1.44$ & $0.43 \pm 1.55$ & 0.485 \\
\hline $7-30$ days & $0.00 \pm 0.00$ & $0.42 \pm 1.44$ & $0.47 \pm 2.31$ & 0.655 \\
\hline $15-30$ days & $0.00 \pm 0.00$ & $0.00 \pm 0.00$ & $0.04 \pm 1.02$ & 0.976 \\
\hline
\end{tabular}

${ }^{*}$ ANOVA F-test, ${ }^{* *}$ F-Statistic from repeated measures ANOVA.

\section{DISCUSSION}

From the patient's point of view, a higher postoperative sensitivity would be an undesired outcome [26]. The objective of present study was to evaluate the presence of postoperative sensitivity in posterior teeth restored with different types of resin composites and adhesive systems as well as the influence of the depth and extension of the dental cavity.

We observed that the materials used, depth and extension of the Class I cavities promoted similar response regarding postoperative sensitivity. This was observed in other study [27]. In addition, a systematic review and metaanalysis performed to evaluated the risk and intensity of postoperative sensitivity in posterior resin composites restorations bonded with selfetch and etch-and-rinse adhesives showed that the type of adhesive strategy for posterior resin composites restorations does not influence the risk and intensity of postoperative sensitivity [8].

It is the responsibility of dental professionals to inform their patients that a treatment of a tooth can cause postoperative sensitivity [14]. Knowledge of scientific evidence, detailed diagnostics, correct treatment planning, experience with various techniques, restorative materials and their clinical indications are essential factors to assure the longevity of restorations and the patient's comfort, as well as the desired esthetics [14].

A high prevalence of postoperative sensitivity was reported in 33\% of 456 teeth restored [28]. In other study, 47\% of 104 restorations in resin composites presented postoperative sensitivity [15]. In addition, no postoperative sensitivity has been found in other study [29]. In the present study, 80 teeth were restored by one operator and approximately $6 \%$ of the total sample, presented postoperative sensitivity. The differences found might be due to the variation of the resin composites and adhesive systems as well as the methodologies of the studies.

The adhesive systems and resin composites resins selected for this study present different 
compositions. These differences led to specific protocols for use as described in materials and methods. In addition, these differences could lead to different levels of postoperative sensitivity reported by patients $[9,30,31]$.

It was reported that the depth of the cavity represents a relevant factor for the emergence of postoperative sensitivity [11]. However, in the present study, the results revealed that cavity depth and extension did not prove to be a relevant factor for postoperative sensitivity. This corroborates a previous study [12]. It has been shown, however, that deeper cavities presents more postoperative sensitivity compared to shallower cavities [26,32]. The differences found may be due to the different materials and methodological approaches [33].

The magnitude of polymerization shrinkage may influence the degree of postoperative sensitivity reported by patients $[1,34]$. A meta-analysis of the literature to assess the clinical behavior of restorations performed with low polymerization shrinkage resin composite in comparison with traditional methacrylates-based resin composite, showed that methacrylates-based composites presented significantly better results than resin composites containing modified monomers [35]. In the present study, all cavities were of Class I type, so we opted for the incremental insertion technique, to minimize the effects of polymerization shrinkage. The purpose of the incremental techniques is to minimize the stress generated by polymerization contraction, inserting resin layers in the cavity and reducing the bonded areas [36,37]. As a result, a lower $\mathrm{C}$-factor allows the resin to flow at the free surfaces [38].

The results, in the present study, showed no difference between the groups ( $\mathrm{p}>0.05$ ), which had resin composites based on methacrylate $\left(\mathrm{ROK}^{\mathrm{TM}}\right.$, Filtek $\mathrm{P}^{\mathrm{TM}}$ and Evolux ${ }^{\mathrm{TM}}$ ) and silorane $\left(\mathrm{P} 90^{\mathrm{TM}}\right)$. The polymerization of resin composites produces stress $[39,40]$. This, however, may not represent an effective threat for postoperative sensitivity, as long as the incremental insertion technique is respected [41-43]. Controversially, the use of a single increment of new bulk-fill material, even in deep cavities, did not generate more postoperative sensitivity when compared to its use in an incremental filling technique [44].

According to the manufacturers' recommendation for self-etching adhesives, a preliminary stage of enamel conditioning was carried out, which did not compromise the performance of such systems, since in the present study, the results revealed that there was no statistically significant difference between the groups that used total or self-etching adhesive systems. This finding may be attributed to the careful attention to the manufacturers' recommendations [6,45-47]. In addition, the risk and intensity of spontaneous postoperative sensitivity was shown to not be affected by the adhesive strategy or the filling technique in posterior composite restorations [48].

The selection of patients for the present research had as inclusion criteria the need for restorative treatment in at least four teeth, so each tooth received a type of resin composite and adhesive system. The purpose of this is that each patient became his own control, as the teeth were subject to the same environmental conditions $[49,50]$.

To measure the postoperative sensitivity, a Visual Analog Scale (VAS) was used. The VAS is an instrument that measures subjective characteristics or attitudes that cannot be directly measured [51]. Thus, the presence of postoperative sensitivity may be influenced by the potential for aggression of the substances used as well as the individual differences in the subjective experience of pain [52]. Even though the analyzes of the results appear very promising, further clinical studies are needed to assess long-term postoperative sensitivity of the associations between the adhesive systems and resin composites used.

\section{CONCLUSION}

The combined resin composites and adhesive systems, depth and extension of the 
Class I cavities promoted similar response regarding postoperative sensitivity in this limited study conditions.

\section{REFERENCES}

1. Anusavice KJ, Shen C, Rawls HR. Phillips' science of dental materials. Rio de Janeiro:Elsevier Health Sciences;2012.

2. Dietschi D. Free-hand composite resin restorations: a key to anterior aesthetics. PractPeriodontics Aesthet Dent. 1995;7(7):15-25.

3. Jang JH, Park SH, Hwang IN. Polymerization shrinkage and depth of cure of bulk-fill resin composites and highly filled flowable resin. Oper Dent. 2015;40(2):172-180. doi:10.2341/13-307-L

4. Buonocore MG. A simple method of increasing the adhesion of acrylic filling materials to enamel surfaces. J Dent Res. 1955;34(6):849-853. doi:10.1177/002 20345550340060801

5. Nakabayashi N, Kojima K, MasuharaE The promotion of adhesion by the infiltration of monomers into tooth substrates. JBiomed Mater Res. 1982;16(3):265-73. doi:10.1002/jbm.820160307

6. 6. Perdigão J,Geraldeli S, Hodges JS. Total-etch versus self-etch adhesive: effect on postoperative sensitivity. J Am Dent Assoc. 2003;134(12):1621-9. doi:10.14219/jada.archive.2003.0109

7. 7. Miyazaki M, Onose H, lida N, Kazama H. Determination of residual double bonds in resin-dentin interface by Raman spectroscopy. Dent Mater. 2003;19(3):245-51. doi:10.1016/s0109-5641(02)00039-8

8. 8. Reis A, Dourado Loguercio A, Schroeder M, Luque-MartinezI, Masterson D, Cople Maia L. Does the adhesive strategy influence the post-operative sensitivity in adult patients with posterior resin composite restorations?: A systematic review and meta-analysis. Dent Mater. 2015;31(9):1052-67.doi:10.1016/.jdental.2015.06.001.

9. Chermont AB, Carneiro KK, Lobato MF, Machado SM, Silva e Souza Junior MH Clinical evaluation of postoperative sensitivity using self-etching adhesives containing glutaraldehyde. Braz Oral Res. 2010:24(3):349-54. doi:10.1590/ s1806-83242010000300015.

10. Berkowitz GS, Horowitz AJ, Curro FA, Craig RG, Ship JA, Vena DA, etal. Postoperative hypersensitivity in class I resin-based composite restorations in general practice: interim results. Compend Contin Educ Dent. 2009;30(6):35663.

11. Auschill TM, Koch CA, Wolkewitz M, HellwigE, Arweiler NB. Occurrence and causing stimuli of postoperative sensitivity in composite restorations. Oper Dent. 2009;34(1):3-10. doi:10.2341/08-7

12. WegehauptF,Betke H, Solloch N, MuschU, Wiegand A, Attin T. Influence of cavity lining and remaining dentin thickness on the occurrence of postoperative hypersensitivity of composite restorations. J Adhes Dent. 2009;11(2): 137-41.

13. Burrow M, Banomyong D, Harnirattisai C, Messer H. Effect of glass-ionomer cement lining on postoperative sensitivity in occlusal cavities restored with resin composite-a randomized clinical trial. Oper Dent. 2009;34(6):648-55. doi:10.2341/08-098-C

14. Briso AL, Mestrener SR, Delicio G, Sundfeld RH,Bedran-Russo AK, de Alexandre RS, et al. Clinical assessment of postoperative sensitivity in posterior composite restorations. Oper Dent. 2007;32(5):421-6. doi: 10.2341/06-141.

15. Casselli DS, Martins LR. Postoperative sensitivity in Class I composite resin restorations in vivo.J Adhes Dent. 2006;8(1):53-8.
16. Murray P,Windsor L, Hafez A, Stevenson R, Cox C.Comparison of pulp responses to resin composites. Oper Dent. 2003;28(3):242-50.

17. de Veras BML, dos Santos Menezes GP,Barros HLM, Rocha MCM, de Carvalho Monteiro A, da Silva Pedrosa M, et al. Clinical performance of class I occlusal composite resin restorations: a multicenter double-blinded randomized clinical trial. Braz Dent Sci. 2018;21(3):288-95

18. Stafuzza TC, Vitor LLR, Rios D, Cruvinel T, Loureço Neto N, Sakai VT, etal. A randomized clinical trial of cavity liners after selective caries removal: one-year follow-up. J Appl Oral Sci. 2019;27:e20180700. doi:10.1590/1678-7757-20180700

19. Craig RG, Curro FA, Green WS, Ship JA. Treatment of deep carious lesions by complete excavation or partial removal: a critical review. J Am Dent Assoc. 2008;139(6):705-12. doi:10.14219/jada.archive.2008.0252

20. Maltz M, Jardim J, Mestrinho H, Yamaguti P,PodestáK, Moura M, etal Partial removal of carious dentine: a multicenter randomized controlled trial and 18-month follow-up results. Caries Res. 2013;47(2):103-9. doi:10.1159/000344013

21. Innes N, Frencken JE, Bjørndal L, Maltz M, Manton DJ, Ricketts D, etal. Managing carious lesions: consensus recommendations on terminology. Adv DentRes. 2016;28(2):49-57.doi:10.1177/0022034516639276

22. Busato A. Dentística: filosofia, conceitos e prática clínica. São Paulo: Artes Médicas; 2005.

23. dos Santos Calderon P,Fernandes Peixoto R, Maron Gomes V, da Mota Corrêa AS, de Alencar EN, Nunes Rossetti LM, etal. Concordance among different pain scales in patients with dental pain. J Orofac Pain. 2012;26(2):126-31.

24. Celik EU,AkaB, YilmazF.Six-month clinical evaluation of a self-adhesive flowable composite in noncarious cervical lesions. J Adhes Dent 2015;17(4):361-8. doi:10.3290/j.jad.a34556

25. Sartori N, Peruchi L, Guimarães J, Silva S, Monteiro Jr S, Baratieri L, et al. Clinical effectiveness of a hydrophobic coating used in conjunction with a one-step self-etch adhesive: an 18-month evaluation. Oper Dent. 2013;38(3):249-57. doi:10.2341/12-014-C

26. Tardem C, Albuquerque EG, Lopes LdS, Marins SS, Calazans FS, Poubel LA, et al. Clinical time and postoperative sensitivity after use of bulk-fill (syringe and capsule) vs. incremental filling composites: a randomized clinical trial. Braz Oral Res. 2019;33(0):e089. doi:10.1590/1807-3107bor-2019.vol33.0089

27. de Oliveira NG, Lima A, da Silveira MT, de Souza Araujo PR, de Melo Monteiro GQ. Evaluation of postoperative sensitivity in restorations with self-adhesive resin: a randomized split-mouth design controlled study. Clin Oral Investig. 2020;24(5):1829-35. doi: 10.1007/s00784-019-03046-0.

28. Unemori M, Matsuya $Y$, Akashi A, Goto $Y$, Akamine A. Self-etching adhesives and postoperative sensitivity. Am J Den. 2004;17(3):191-5.

29. Arhun N, Celik C, Yamanel K. Clinical evaluation of resin-based composites in posterior restorations: two-year results. Oper Dent. 2010;35(4):397-404. doi:10.2341/09-345-C

30. PerdigÃO J, Geraldeli S, Hodges JS. Total-etch versus self-etch adhesive: Effect on postoperative sensitivity. J Am Dent Assoc. 2003;134(12):1621-9. doi:https:// doi.org/10.14219/jada.archive.2003.0109.

31. De Munck J,Van LanduytK, Peumans M, Poitevin A, Lambrechts P,Braem M, et al. A critical review of the durability of adhesion to tooth tissue: methods and results. JDentRes. 2005;84(2):118-32. do: 10.1177/154405910508400204.

32. Unemori M, Matsuya Y,Akashi A, Goto Y,Akamine A. Composite resin restoration and postoperative sensitivity: clinical follow-up in an undergraduate program. J Dent. 2001;29(1):7-13. doi:10.1016/s0300-5712(00)00037-3 
33. Eames W, Reder B, Smith G. Cutting efficiency of diamond stones: effect of technique variables. Oper Dent. 1977;2(4):156-64.

34. van Dijken JW,Pallesen U. A randomized controlled three year evaluation of "bulk-filled" posterior resin restorations based on stress decreasing resin technology.DentMater.2014;30(9):e245-e51. doi:10.1016/j.dental.2014.05.028

35. Kruly PC, Giannini M,Pascotto RC, Tokubo LM, Suga USG, Marques ACR, et al. Meta-analysis of the clinical behavior of posterior direct resin restorations: Low polymerization shrinkage resin in comparison to methacrylate composite resin. PLoS One. 2018;13(2):e0191942. doi:10.1371/journal.pone.0191942

36. França FMG, Hori FS, Santos AJSd, Lovadino JR. The effect of insertion and photopolymerization techniques on microleakage of Class $V$ cavities: a quantitative evaluation. Braz Oral Res. 2005;19(1):30-5. doi:10.1590/s180683242005000100006

37. Bicalho AA, Valdivia AD, Barreto BC, Tantbirojn D, Versluis A, Soares CJ. Incremental filling technique and composite material--part ll: shrinkage and shrinkage stresses. Oper Dent. 2014;39(2):E83-92. doi: 10.2341/12-442-I.

38. Carvalho RMd, Pereira JC, Yoshiyama M, Pashley DH. A review of polymerization contraction: The influence of stress development versus stress relief. Oper Dent. 1996;21(1):17-24.

39. Ferracane JL, Hilton TJ. Polymerization stress-is it clinically meaningful? Dent Mater.2016;32(1):1-10. do:10.1016/j.dental.2015.06.020

40. Giachetti L, Scaminaci Russo D, Bambi C, Grandini R. A review of polymerization shrinkage stress: current techniques for posterior direct resin restorations. J Contemp DentPract. 2006;7(4):79-88.

41. Klautau EB, Carneiro KK, Lobato MF,Machado SMM. Low shrinkage composite resins: influence on sealing ability in unfavorable $\mathrm{C}$-factor cavities. Braz Oral Res. 2011;25(1):5-12. doi:10.1590/s1806-83242011000100002

42. Al-Boni R, Raja OM. Microleakage evaluation of silorane based composite versus methacrylate based composite. J Conserv Dent. 2010;13(3):152-5. doi:10.4103/0972-0707.71649
43. Eick.JD. Polymerization shrinkage of posterior composite resins and its possible influence on postoperative sensitivity. Quintessence Int. 1986;17:103-11.

44. Costa T, Rezende M, Sakamoto A, Bittencourt B, Dalzochio P, Loguercio AD, et al. Influence of adhesive type and placement technique on postoperative sensitivity in posterior composite restorations. Oper Dent. 2017;42(2):143-54. doi: 10.2341/16-010-c.

45. Pashley DH, Ciucchi B, Sano H, Horner JA. Permeability of dentin to adhesive agents. Quintessence Int. 1993;24(9):618-31.

46. Pashley DH. Dentin permeability and dentin sensitivity. Proc Finn Dent Soc. 1992;88 Suppl 1:31-37.

47. Pashley DH. Dentin permeability, dentin sensitivity, and treatment through tubule occlusion. JEndod. 1986;12(10):465-74. doi:101016/S00992399(86)80201-1

48. da Costa J, Vargas M, SwiftEJ, Jr, AndersonE, Ritter S. Color and contrast ratio of resin composites for whitened teeth. JDent. 2009;37 Suppl 1:e27-33. doi: 10.1016/j.jdent.2009.05.005.

49. Antczak-Bouckoms AA, Tulloch JF,Berkey CS. Split-mouth and cross-ove designs in dental research. J Clin Periodontol. 1990;17(7Pt1):446-53. doi: 10.1111/j.1600-051x.1990.tb02343.x.

50. Zanatta RF, da Silva TM, Esper MALR, Bresciani E, Caneppele TMF, de Paiva Gonçalves SE. Guidelines for conducting split-mouth clinical studies in restorative dentistry. BrazDen Sci. 2017;20(2):29-37.

51. Bijur PE, Silver W, Gallagher EJ. Reliability of the visual analog scale for measurement of acute pain. Acad Emerg Med. 2001;8(12):1153-7. doi:10.1111/j.1553-2712.2001.tb01132.x

52. Afifi SMH, Haridy MF, Farid MR. Evaluation of post-operative sensitivity of bulk fill resin composite versus nano resin composite: a randomized controlled clinical study. Open Access Maced J Med Sci. 2019;7(14):2335- 42. doi:10.3889/ oamims.2019.656.

\section{Claudio Heliomar Vicente da Silva}

(Corresponding address)

Departamento de Prótese e Cirurgia Buco-facial, Universidade Federal de Pernam-

buco, Av. Prof. Moraes Rego, S/N, CDU. 50670-901 Recife/PE, Brasil

Date submitted: 2020 Feb 02

E-mail: claudio_rec@hotmail.com 